\title{
15. SIGISMUND TODUŢĂ. COMPONENT PORTRAIT
}

\begin{abstract}
Marta Burduloi ${ }^{130}$
Absctract: The figure of the composer Sigismund Toduţă is among those creators whose style, although having a constant evolution towards complexity over several creative periods, remains essentially unitary from a stylistic point of view, rendering it recognizable by constant compositional masterpieces throughout his entire work. ${ }^{131}$ The existence of a significant number of studies, articles, analyses, integrated in various journalistic contexts (magazines, lexicons, doctoral theses), concerning various aspects of Toduţă creation, has made it possible to outline even from the beginning a general picture of the composer's style, a valuable starting point for deepening the research in the spirit of the chosen theme.
\end{abstract}

Key words: originality, creativity, Romanian music

\section{Introduction}

By following fundamental creation parameters that contribute to the configuration of the musical language of the composer Sigismund Toduţă (chromatic, rhythmic, polyphony, forms), through a very well-founded study from a musicological perspective, Vasile Herman performs a first attempt to synthesize the stylistic aspects that customize the composer's creation. ${ }^{132}$ Vasile Herman names the stylistic coordinates of Toduţă creation: the European tradition of Renaissance, Baroque and Classicism, the Romanian folklore, the (Gregorian and Byzantine) "medieval song intonations", the inheritance of the Romanian musicians". ${ }^{133}$

\section{Sound sources in Sigismund Toduţă creation}

In such sound worlds, Sigismund Toduţă imagination and creative force leave their mark on the 20th century componistic. In this sense, we can also refer to the sources of chromatic thinking that characterize the composer's creation: the Gregorian and Byzantine modal, as well as the Romanian folklore, adding solutions obtained from the almost contemporaries Enescu, Bartok, Messiaen. Given that Sigismund Toduţă works, during the creation periods, do not show any significant changes in style, they can be presented in genres and forms, depending of course on the aesthetic attitude of the composer.

From the point of view of the musicologist Romeo Ghircoiaşu a first stage of creation is under the sign of "a thorough and scientific study of popular

\footnotetext{
130 Assistante PhD., "George Enescu" National University of Arts from Iaşi, Romania, email: martinica_79@yahoo.com

${ }^{131}$ MagazineMuzica, no.6, 1965 - p.24

132 MagazineMuzica, no.6, 1965 - p.25

${ }^{133}$ MagazineMuzica, no.12, 1969 - p.3
} 
musical language", reflected by the currently appeared works - "Cello Sonata"; "Violin Sonata"; "Flute Sonata"; "Piano Sonatina", "Concerto for strings"; Symphony No. 1 and Symphony No. 2, choral pieces like "Country Wedding" or carols adaptations, this period being characterized by the composer's concern for an original expression, anchored in contemporaneity, but of national specific.|

The second stage reflects the language and architecture renewal, consisting in the "re-molding of the material into unitary shapes "and the capitalization of the cyclical principle - aspects reiterated in Symphony No. 3 and in Symphony No. 5, "Concert for Wind and Percussion Instruments", "Old Stamps". We also need to mention the three choirs that were composed at the same time as the first version of the oratories "Mioriţa" and "In the Wake of Horea". The third creative period in Romeo Ghircoiasu vision includes a new version of "The Master Builder Manole" work, in an "ample trilogy that embodies three major symbols of our popular thinking and creation". ${ }^{134}$

The last decade of life and creation of the master of Cluj appears as a superior stage in the edification of his creative universe in exceptional works of the choral, vocal, chamber and concert genre, like madrigals and lieds with lyrics by Lucian Blaga and Ana Blandiana, concerts for piano and flute, piano and oboe, solo sonatas for flute and cello, Sonata No. 2 for violin and piano, Choral - preludes for organ. If we try to situate Sigismund Toduță in contemporary Romanian creation, "we must say that after Enescu and Paul Constantinescu, Master Toduţă is the only author who has reached his own, original, unique, harmonic language"135, Dan Voiculescu concludes his article entitled "A Higher Understanding of the Role of Art", dedicated to the 80th anniversary of the birth of the Creator from Cluj.

Thus, Sigismund Toduţă is a continuator of Enescu's musical principles on several levels. The composer associates himself with the idea of "synthesizing elements of national and universal culture in the form of a European technique of composition with Romanian folklore" ${ }^{136}$ as well as with classical Romanian music. The principles of cyclical thinking taken from the French tradition (Frank, d'Indy), developed in a musical language that is different from Western music, concerned Sigismund Toduţă, as evidenced by his symphonies, concerts for string orchestra, sonatas and sonatines.

\section{Stylistic aspects}

One of the important issues in the creation of Toduţă is the analysis from the perspective of vocalism and choir music. "If music needs a word sometimes, it's because it tries to reunite with that unconcealed Word of concept, the word

\footnotetext{
${ }^{134}$ Magazine Muzica, no.4, 1979 - p.12.Study performed by Vasile Herman

${ }^{135}$ Voiculescu, Dan - „O înţelegere superioară a rolului artei”, dedicated to the 80th anniversary of the birth of Sigismund Toduţă

${ }^{136}$ Magazine Muzica, no. 4, 1979 - „Pe urmele lui Horea”, study performed by Vitterman, p.13
} 
that simply embodies human presence (the human voice being the universal aesthetic medium: all instruments are but" masks "of the human voice.)" ${ }^{\prime 37}$ From this fragment quoted in the work "Melopoetica" by Greta Tartler, it is important to treat the voice, whether soloist or not, in vocal or vocal-symphonic or choral genre - in the configuration of some fundamental stylistic aspects of the creation of Toduţă. In the folkloric adaptations of the first creation period, the phenomenon becomes more detached, especially since the harmonic-polyphonic approach of madrigal or variation type implies the multiplication and equal importance of the voices and the movement of the themes from one voice to the other during musical discourse.

These are the three choir notebooks, "Triptic", "Five Chorus for Men's Voices" and "6 Folk Songs", but also the cycle of lieds entitled "4 Folk Songs". And the instrumental creation of this period can also be seen as vocalist: I refer to "Passacaglia", having as theme a star song, "Romanian Folk Dances and Songs" or even "Symphonic Variations on a Popular Issue" all based on a melodic idea of folkloric origin. However, which are actually those elements that define the vocal profile of a song, distinguishing it from an instrumental one? In this sense, I shall present the specific melodic forms, ambitus, inner and final tempos. The Byzantine-Gregorian-folkloric fusion is found in the extreme sections of the choral poem "Archaisms", or in the pages of the oratory piece "The Master Builder Manole", as well as in other works. E.g.1 "Archaisms"

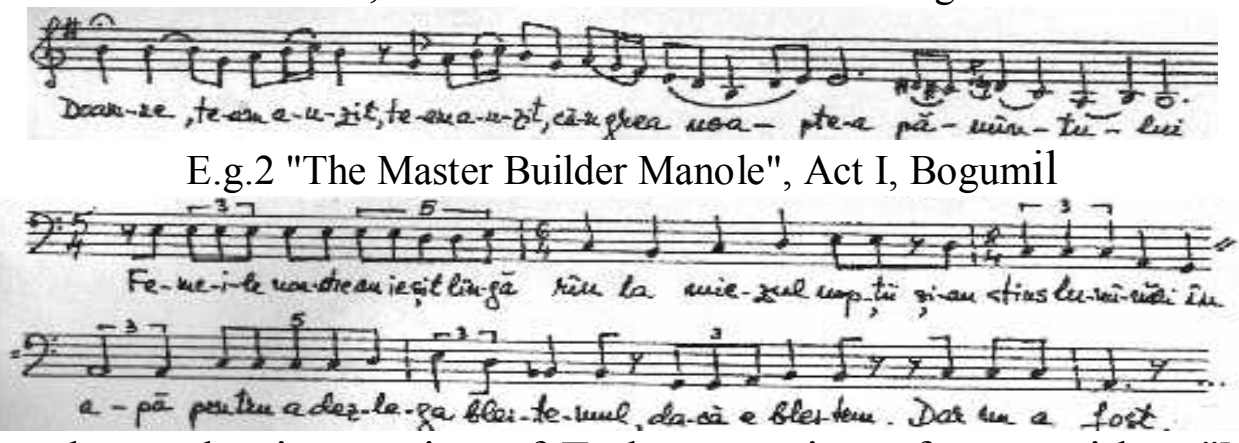

The vocal-symphonic creation of Toduţă consists of seven titles: "Mena", "Psalm 97", "Psalm 133", "Mioriţa", "Ballad of the Flag", "In the Wake of Horea", "The Master Builder Manole". Of the seven works, the first three are delimited as a distinct, early stage, by religious character and by language elements. The other four works fall into the oratory genre, ("In the Wake of Horia") or intersected with other related genres: "Mioriţa" oratorio-ballad, "Ballad of the Flag", oratorio-piece "The Master Builder Manole". They prove the stability and unity of the musical language of the composer in a particular way in relation to the evolution of other genres.

As Zeno Vancea shows, the "oratory Mioriţa is subdivided into twelve sections which follow the music line without interruption, and, depending on the text (in the version of Vasile Alecsandri) the music has a both lyrical and dramatic character, the epic element being present through some interventions,

${ }^{137}$ Tartler, Greta - "Melopoetica", p.35 
in the form of comments of the choir. Using the same unified language in the course of musical performance, the composer brought with this work a new proof of the broad possibilities of expressing a musical language that has its roots in folklore, the personal stylization of its elements depending on the needs of musical content interpretation of lyrics poetic content"

The "Ballad of the Flag", designed for solo (soprano) voice, choir and orchestra, is "a page of the troubled past of the nation, a pathetic fresco [...] that takes place at the level of tension and epic-drama-oratory climate." ${ }^{138}$ By choosing the subject and the way of its musical approach, by his work "In the Wake of Horia" Sigismund Toduţă aims at "the realization of a passion type oratory related to the monumental works of the late Baroque music." 139

The Master Builder Manole, in the final version of the '80s, crowns the composer's extensive choral and vocal experience, along with the artistic and aesthetic implications of deep significance, turning into a remarkable work in the contemporary Romanian context. The approach and the "fluctuation" of the drama subject, "7 times 7 years", is part of the Belgian zodiac sign, which focuses on a good part of the Toduță creation, both in the vocal-symphonic and in the choral or vocal genre " ${ }^{140}$ Due to the obvious approaches and syntax of the languages used in the four works, dealing in parallel with the vocal and choral style aspects will allow a better fit in a unitary picture.

The choral ensemble fulfills multiple functions in the works dramaturgy, either as a relatively active participant in the action ("In the Wake of Horea" the choir represents the crowd, the people, "The Master Builder Manole" - the builders), or commentator, storyteller, as in ancient Greek tragedies ) "Mioriţa", "The Master Builder Manole", "In the Wake of Horea") or sound background, creating atmosphere ("In the Wake of Horea", "The Master Builder Manole"). The composer's preference for detached groups in the choral group generates a great diversity of choral pages. Among these groups is the men's choir (composed of T1-T2, B1-B2, exploited to the maximum in various situations (active or passive). "The Master Builder Manole" - the builders; "Mioriţa" - the storyteller; "In the Wake of Horea" - the people. More rarely the composer uses the women's choir - a single number in "Mioriţa" (no.2) in "The Master Builder Manole" (no.13), "In the Wake of Horea" $(2,7,10,12,16)$. E.g.3 "In the Wake of Horea", VII, m.1 - 8

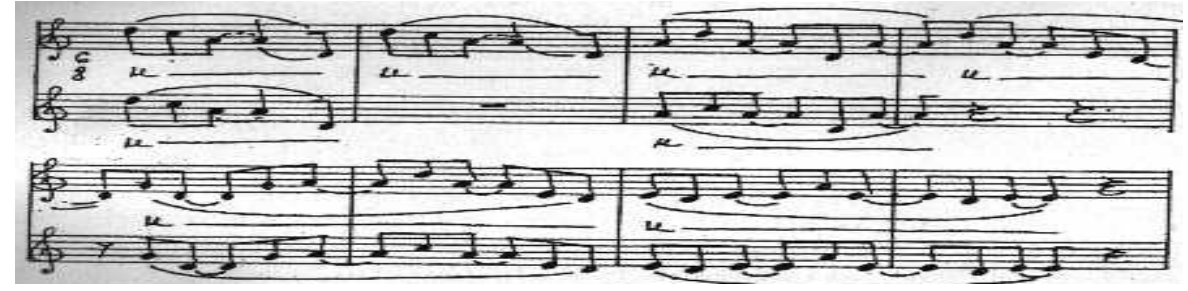

\footnotetext{
${ }^{138}$ Magazine Muzica, no.5, 1981 - „Lucian Blaga cântat de Sigismund Todutăă”, p.45

${ }^{139}$ Magazine Muzica, no.4, 1979 - „Pe urmele lui Hora”, paper by Vasile Herman, p.13

140 Magazine Muzica , 1977 -,, Sigismund Toduţă”, paper by Zeno Vancea, p. 16
} 
E.g.4 "The Master Builder Manole", Act III, no.62, m.1-2

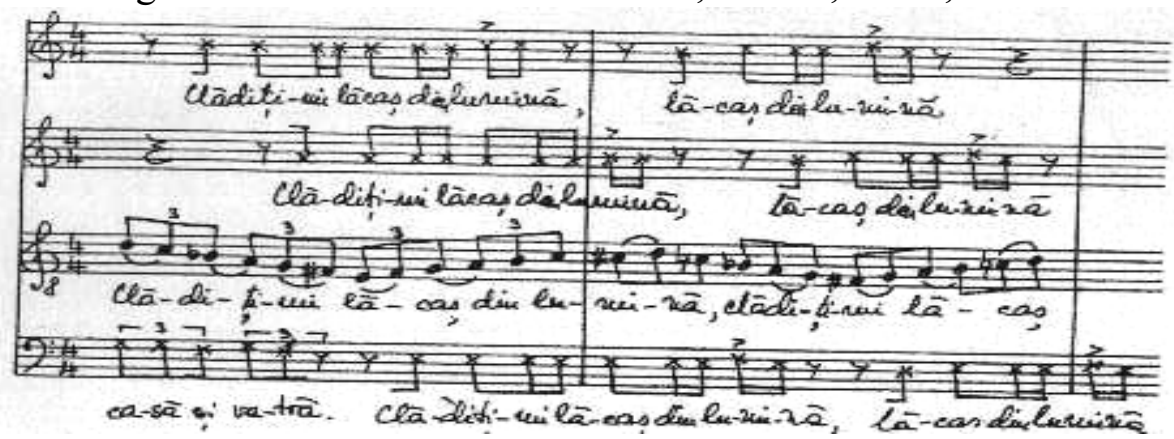

From the point of view of the choral apparatus approach, Sigismund Toduţă capitalizes the vocal possibilities of a normal ambitus, the accents being put on the issues of harmonic and polyphonic writing, entrusted to the ensemble. Of these, the melodic profile of the various vocal parties falls within the typologies already encountered in the genre of the choral or vocal genre, characterized by the folk or Byzantine folk melody, specific to the parlando - rubato style, in which the text is divided into an asymmetric rhythmical and "wavy" drawing by the variety of successive durations. E.g.5a "In the Wake of Horea", XVII, m.6-10

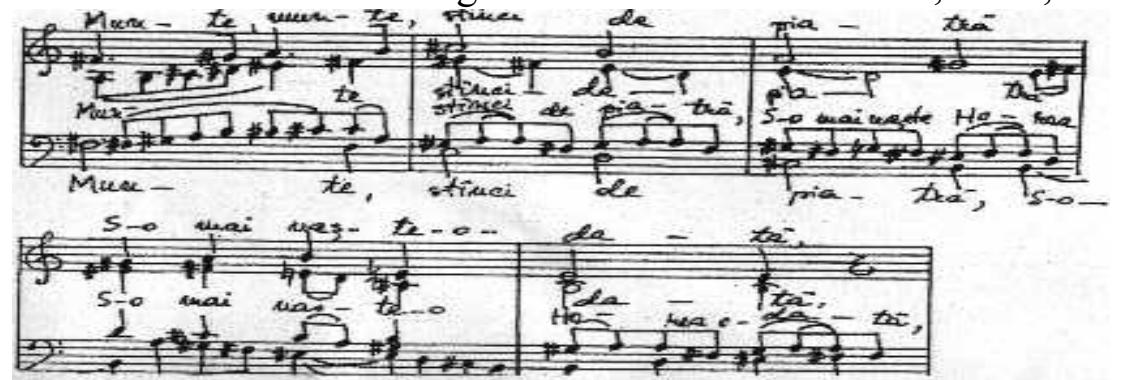

E.g.5b "In the Wake of Horia," II, m.27-30, alto

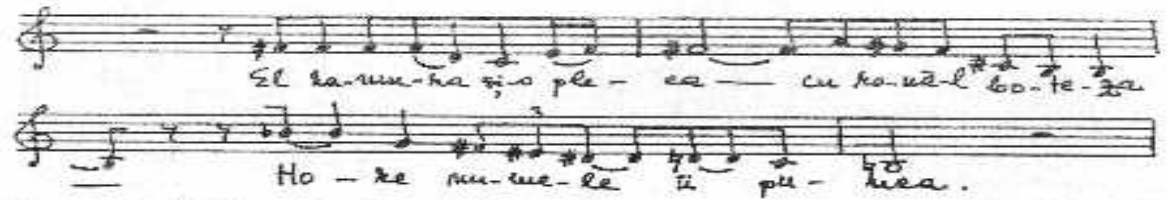

Among the special aspects of voice treatment, the "Sprechgesang" (imprecise height speech), moderately encountered in other vocal genres as well, will have an intense application (especially the "The Master Builder Manole" in contexts with reference to mocking, shouting as well folklore incantations. E.g.6a "The Master Builder Manole," Act I, 11a

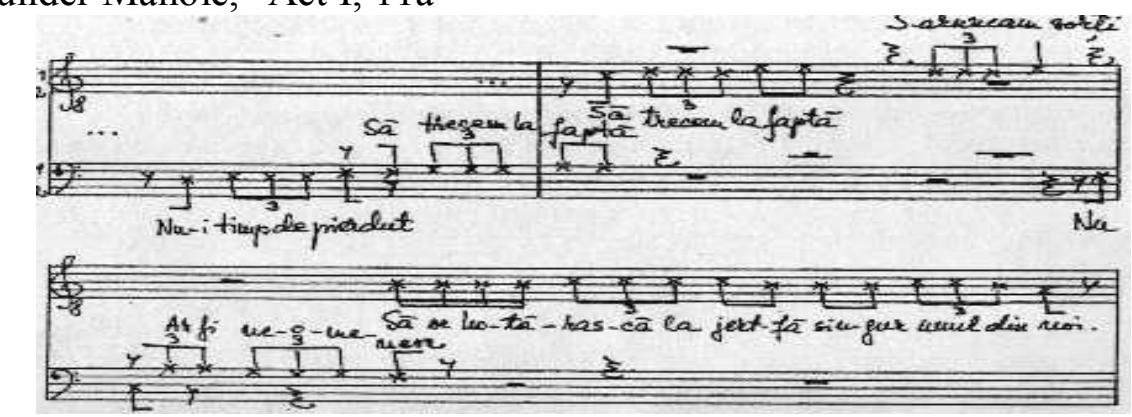

E.g.6b "In the Wake of Horea", VIII, m.5-9

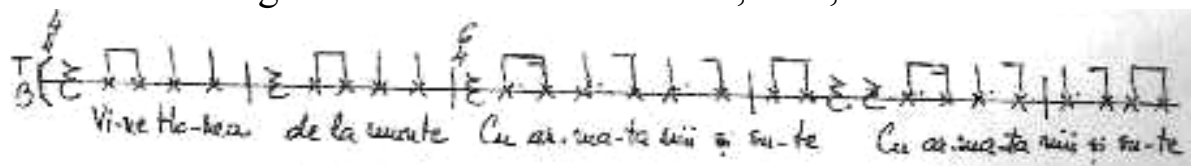


From the point of view of the number of characters and the type of voice to which the composer entrusts his part, we must note that these aspects vary from one voice to another: "Miorița", - soprano (Mioriţa), alto (mother), tenor (shepherd); "Ballad of the Flag" - soprano; "In the Wake of Horea" - tenor, bass (Horea); "The Master Builder Manole": lyrical-dramatic soprano (Mira), baritone - Manole, baritone - reciter (Gaman), lyrical bass - Bogumil. We mention that for the solo voices of "The Master Builder Manole", the composer chose some intermediate categories of the respective types of voices, thus specifying his timbral - expressive intentions in shaping the individuality of the characters. The lyrical-dramatic soprano combines the characteristics of the dramatic type (the highest ambitus, multiple vocal possibilities) with the lyrical type (softer, more penetrating, and subtle).

Sigismund Toduţă does not regard vocal virtuosity through the abundance of acute abundance; when he uses these, they are very well prepared. The composer's attention focuses on the clarity and fidelity of text sound picture, especially through accents and intervals, against the background of permanent equality between text and music. E.g.7 "The Master Builder Manole", Act III, 72a, Manole

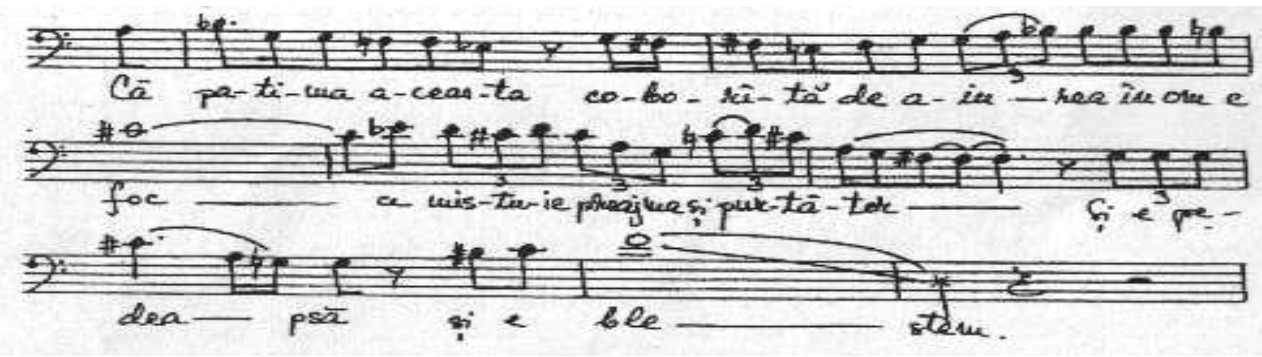

\section{Conclusions}

If we are to conclude on the composer's style in treating the integrated voice of the choral apparatus, I would like to make a first specification: In this study, I wanted to approach the vocal and choral issue from my own perspective; I shall refer to my vocal concerns. Hence, all the observations and arguments are based on my point of view, because they were born out of the practice of singing, of my personal interpretative vision. Thus, returning to Toduţă text-based works, I would like to point out that one of the fundamental preoccupations of his reign was to obtain the clarity of the text - indispensable for the transmission of the artistic message. In order to achieve this goal, the composer uses the recitative and lyrical tempo of the melody in an original synthesis, predominantly the parlando lyric of folkloric origin.

The stylistic aspects of Toduţă creation (melody, polyphony, form, rhythm) are enhanced by the timbral aspect, whose variety appears as another essential concern of the composer in line with the concerns of the great creators of the 20th century in this field (De Falla, Messiaen, Ravel, Bartok, Stravinski, Xenakis). This is reflected not only by the different types of ensembles (mixed 
choir, female choir), to whom the composer dedicates his choral works, but mostly through the multiple ramifications of choral writing.

Moreover, we cannot conclude without the words of the composer himself who, referring to Blaga's poetic admiration, indirectly characterizes himself: "I fell into the magic circle of the Lancrăm poet. Like the builders of the Master Builder Manole, fascinated by the "little face of the place", I also uttered the words with them: "Master builder, here we come!" However, unlike the builders gathered to build of earth and water, of light and wind, I stand in the Belgian magic sky trying to understand the meaning of the accents, the meaning of the thoughts, the depth of the symbols and the charm of the metaphor. And from the symbol of passion grafted in the soul, from the passion of the building he masterly sings in the drama The Master Builder Manole, I also asked the same question as the poet: For what mysterious fault was I punished with the longing to conceive beauty?, hanging near this rare subject for half a century. "141

\section{References}

1. Berger, Wilhelm - Sigismund Toduţă, The Magazine Muzica, no.8, 1983

2. Firca, Gheorghe - Sigismund Toduţă, The Magazine Muzica, no.4,1998

3. Gherman, Liliana - Meşterul Manole, Magazine Muzica, no.4, 1990

4. GhermanN, Liliana - Unele aspecte ale relaţiei text şi muzică în creaţia lui Sigismund Toduţă, Magazine Muzica, no.7, 1987

5. Herman, Vasile - Sigismund Toduţă, Magazine Muzica, no.6, 1965

6. Herman, Vasile - Oratoriul Pe urmele lui Horea de Sigismun Toduţă, Magazine Muzica, no.4, 1979

7. Juch Santa, Doina - Contribuţii la exegeza operei lui Sigismund Toduţă. The Magazine Muzica, no.10-11, 1980

8. Popovici, Doru - Liedurile lui Sigismund Toduţă, Magazine Muzica, no.1, 1993

9. Pop, Rodica and Moldovan, Mihai - Lucian Blaga cântat de Sigismund Toduţă, Magazine Muzica, no.5-6, 1981

10. Stoianov, Carmen - Mioriţa în creaţia compozitorilor Paul Constantinescu, Anatol Vieru şi Sigismund Toduţă, Studii de muzicologie, X, Bucharest, 1974

11. Țăranu, Cornel - Meşterul Manole de Sigismund Toduţă, Magazine Muzica, nr.6, 1986

12. Țăranu, Cornel - Mioriţa. Baladă-oratoriu de Sigismund Toduţă, Magazine Muzica, no.12, 1969

13. Vancea, Zeno - Sigismund Toduţă, Magazine Muzica, no.4, 1977

${ }^{141}$ Magazine Muzica, no.6, 1986. „Meşterul Manole” by Sigismund Toduţă, paper by Cornel Ţăranu, p.7 